\title{
A calcium antagonist, nifedipine, modifies exercise-induced asthma
}

\author{
PETER J BARNES, NICOLA M WILSON, MORRIS J BROWN
}

From the Departments of Medicine, Child Health, and Clinical Pharmacology, Royal Postgraduate Medical $\overrightarrow{\overrightarrow{2}}$ School, Hammersmith Hospital, London

ABSTRACT In eight extrinsic asthmatic subjects (age range 16-38 years) there was a significant reduction $(\mathrm{p}<0.01)$ in the severity of bronchoconstriction after a treadmill exercise test performed $\tilde{\sigma}$ 30 minutes after nifedipine $20 \mathrm{mg}$ sublingually. The maximum fall in peak expiratory flow after응 exercise was $36.0 \pm$ SEM $5 \cdot 3 \%$ compared with a maximum fall of $56.5 \pm 4.1 \%$ after matched $\overrightarrow{-}$ placebo capsules when given in double-blind randomised manner on separate days. There was no@ significant resting bronchodilation or change in blood pressure or heart rate after nifedipine. There $\frac{0}{0}$ was a significant rise in venous plasma histamine during exercise with placebo $\left(6 \cdot 1 \pm 0.8\right.$ to $13.5 \pm \frac{\mathbb{Q}}{7}$ $3.5 \mathrm{nmol} / \mathrm{l}, \mathrm{p}<0.01)$ but no significant increase with nifedipine $(4.6 \pm 0.6$ to $4.7 \pm 0.6 \mathrm{nmol} / \mathrm{l}) \vec{\bigotimes}_{\infty}$ suggesting that nifedipine inhibits the release of mast cell mediators. The dose of inhaled histamine.which provoked a $20 \%$ fall in peak expiratory flow was also significantly higher $(\mathrm{p}<0.05)$ with nifedipine $(1.5 \pm 0.31 \mathrm{mg} / \mathrm{ml})$ compared with placebo $(2.7 \pm 0.63 \mathrm{mg} / \mathrm{ml})$, indicating that there is a small inhibitory effect on bronchial smooth muscle contractility. Nifedipine is a potent antagonist of calcium ion influx in smooth muscle and secretory cells, and these studies suggest that it may inhibit release of mast cell mediators and reduce bronchial smooth muscle contractility in asthma.

Calcium ions are involved in contraction of smooth muscle and in secretory processes. Inhibition of transmembrane calcium ion influx should be beneficial in asthma which involves both contraction of bronchial smooth muscle and secretion of bronchoconstrictor mast cell mediators. ${ }^{1}$ Nifedipine is a potent antagonist of calcium ion influx across cell membranes and a recent report suggests that it inhibits exercise-induced asthma (EIA). ${ }^{2}$ We have studied the effect of nifedipine in EIA, and measured bronchial smooth muscle contractility by histamine

Address for reprint requests: Dr PJ Barnes, Department of Medicine, Royal Postgraduate Medical School, Hammersmith Hospital, London W12 0HS. inhalation challenge and mast cell mediator release? by the changes in circulating plasma histamine? during exercise.

\section{Methods}

Eight asthmatic subjects aged 16-38 years with multiple positive skin tests and previously documented EIA were studied (table 1). Approval for the study was obtained from the Ethics Committee of $\mathrm{O}$ Hammersmith Hospital and all subjects gave informed consent. All medications were withdrawn for at least eight hours before study and none of the subjects was taking cromoglycate or oral steroid therapy.

Table 1 Subjects and baseline spirometry

\begin{tabular}{|c|c|c|c|c|c|c|c|}
\hline Subject & $\operatorname{Sex}$ & Age $(y r)$ & Height $(m)$ & $F E V_{1}(l)$ & $F E V_{1}(\%$ predicted $)$ & $V C(l)$ & $V C(\%$ predicted $)$ \\
\hline $\begin{array}{l}1 \\
2 \\
3 \\
4 \\
5 \\
6 \\
7 \\
8\end{array}$ & $\begin{array}{l}\mathbf{M} \\
\mathbf{M} \\
\mathbf{M} \\
\mathbf{M} \\
\mathbf{F} \\
\mathbf{M} \\
\mathbf{F} \\
\mathbf{M}\end{array}$ & $\begin{array}{l}27 \\
28 \\
24 \\
17 \\
38 \\
37 \\
16 \\
18\end{array}$ & $\begin{array}{l}1.79 \\
1.68 \\
1.83 \\
1.55 \\
1.58 \\
1.73 \\
1.67 \\
1.80\end{array}$ & $\begin{array}{l}3 \cdot 7 \\
1.6 \\
4 \cdot 3 \\
1 \cdot 5 \\
2.4 \\
3 \cdot 2 \\
2.4 \\
1.8\end{array}$ & $\begin{array}{l}86 \\
42 \\
96 \\
48 \\
96 \\
84 \\
75 \\
45\end{array}$ & $\begin{array}{l}5 \cdot 1 \\
2 \cdot 6 \\
5 \cdot 8 \\
2 \cdot 6 \\
3 \cdot 4 \\
5 \cdot 3 \\
4 \cdot 2 \\
3 \cdot 7\end{array}$ & $\begin{array}{r}96 \\
58 \\
104 \\
74 \\
106 \\
115 \\
105 \\
77\end{array}$ \\
\hline $\begin{array}{l}\text { Mean } \\
\text { SEM }\end{array}$ & & $\begin{array}{r}25.6 \\
3.0\end{array}$ & $\begin{array}{l}1 \cdot 70 \\
3.6\end{array}$ & $\begin{array}{l}2 \cdot 6 \\
0 \cdot 36\end{array}$ & $\begin{array}{r}71 \cdot 5 \\
8 \cdot 1\end{array}$ & $\begin{array}{l}4 \cdot 1 \\
0 \cdot 43\end{array}$ & $\begin{array}{r}91.9 \\
7.0\end{array}$ \\
\hline
\end{tabular}


The studies were performed in an air-conditioned laboratory under constant environmental conditions (temperature $22^{\circ} \mathrm{C}$, relative humidity $45 \%$ ). The second test was performed at the same time of day as the first for an individual subject and within a period of 14 days.

A small cannula (Butterfly $19 \mathrm{G}$ ) was inserted into a forearm vein for later blood sampling. $\mathrm{FEV}_{1}$ and vital capacity were measured using a dry spirometer (MacDermott) and peak expiratory flow (PEF) by a Wright peak flow meter (Airmed UK). Measurements were made in triplicate and the best value recorded. Blood pressure and heart rate were also recorded.

Subjects then received either nifedipine $20 \mathrm{mg}$ or placebo in randomised double-blind manner on separate days. They were instructed to bite the capsule and keep the fluid in the mouth as long as possible to aid buccal absorption. Placebo capsules were identical in appearance and contained a liquid with an identical peppermint taste. Thirty minutes after dosing, blood was taken for measurement of plasma histamine, then spirometry, PEF, blood pressure, and heart rate recorded. Subjects then performed an exercise test on a treadmill running at $6 \mathrm{~km} /$ hour with a gradient of $8-10 \%$, depending on previously measured exercise lability. The duration of exercise was six minutes and blood was sampled during the last minute of running. The PEF was recorded after exercise at one, three, and five minutes, then every five minutes until a spontaneous rise occurred. An identical treadmill slope and speed was used on the second study day. In five subjects, 90 minutes after dosing, when PEF had returned to baseline values, a histamine inhalation challenge was performed using a standardised technique. ${ }^{3}$ Subjects inhaled five inspiratory capacity breaths from a Wright nebuliser of serial dilutions of histamine acid phosphate solution. The concentration of histamine provoking a $20 \%$ fall in PEF three minutes after inhalation $\left(\mathrm{PC}_{20}\right)$ was calculated.

Blood was collected into chilled plastic tubes with $0.1 \%$ EDTA and centrifuged at $4^{\circ} \mathrm{C}$. Plasma was stored at $-80^{\circ} \mathrm{C}$ and all samples were assayed at the same time. Histamine was measured by a radioenzymatic assay using guinea pig brain histamine $\mathrm{N}$-methyl transferase. ${ }^{4}$ High sensitivity and specificity was achieved by incorporating a thin layer chromatography stage, and precision by using $\mathrm{N}$ methyl histamine as an internal standard in each sample. The intra-assay coefficient of variation was $4.9 \%$ and the sensitivity was $0.36 \mathrm{nmol} / 1$.

All results were compared by Wilcoxon matched pairs signed rank test, apart from the histamine challenge results which were analysed by a paired Student's $t$ test.

\section{Results}

When compared to placebo nifedipine produced no significant increase in $\mathrm{FEV}_{1}$, vital capacity, or PEF 30 minutes after dosing. No subjects complained of side-effects and there were no significant changes in blood pressure or heart rate. After exercise the maximum fall in PEF was significantly less ( $p<$ $0.01)$ with nifedipine $(36.0 \pm$ SEM $5.3 \%)$ compared with placebo $(56.5 \pm 4.1 \%)$ (table 2$)$ and the PEF was significantly higher at all times after exercise with nifedipine (fig 1). In one subject (3) nifedipine completely inhibited EIA but in two subjects ( 5 and 7) there was no inhibition; five subjects showed partial inhibition. There was no significant difference in baseline lung function between the nifedipine and placebo days.

Plasma histamine levels rose significantly ( $p<$ 0.01 ) during exercise with placebo but there was no significant rise during exercise when on nifedipine (table 2, fig 2). Furthermore the pre-exercise plasma

Table 2 Effect of placebo and nifedipine on maximum fall in peak flow (PEF) after exercise, venous plasma histamine, before and during exercise and $P C_{20}$ to inhaled histamine in asthmatic subjects

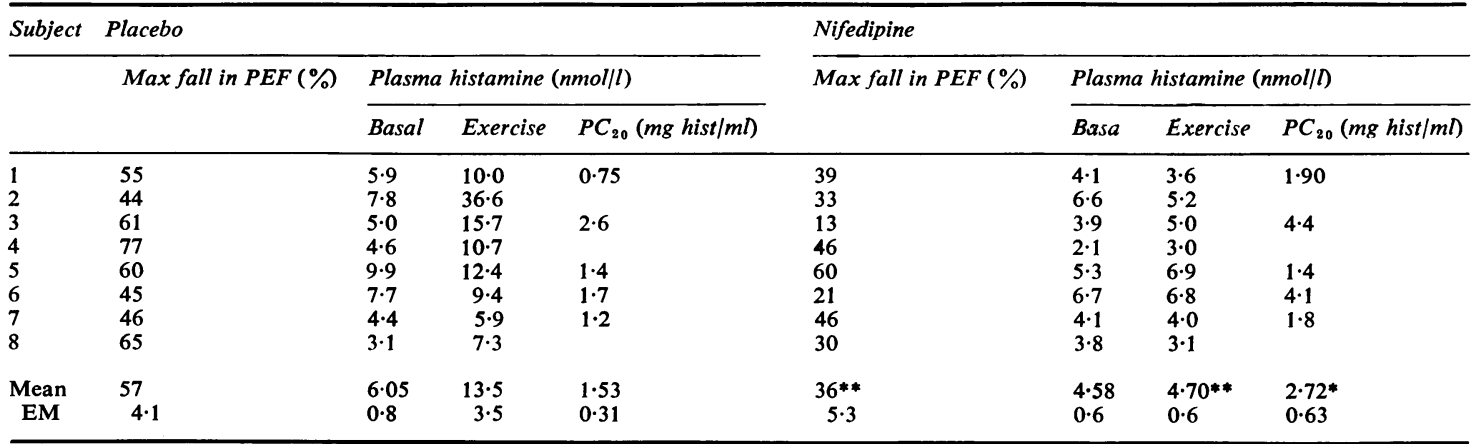

Difference between placebo and nifedipine treatments: ${ }^{*} p<0.05,{ }^{* *} p<0.01$. 


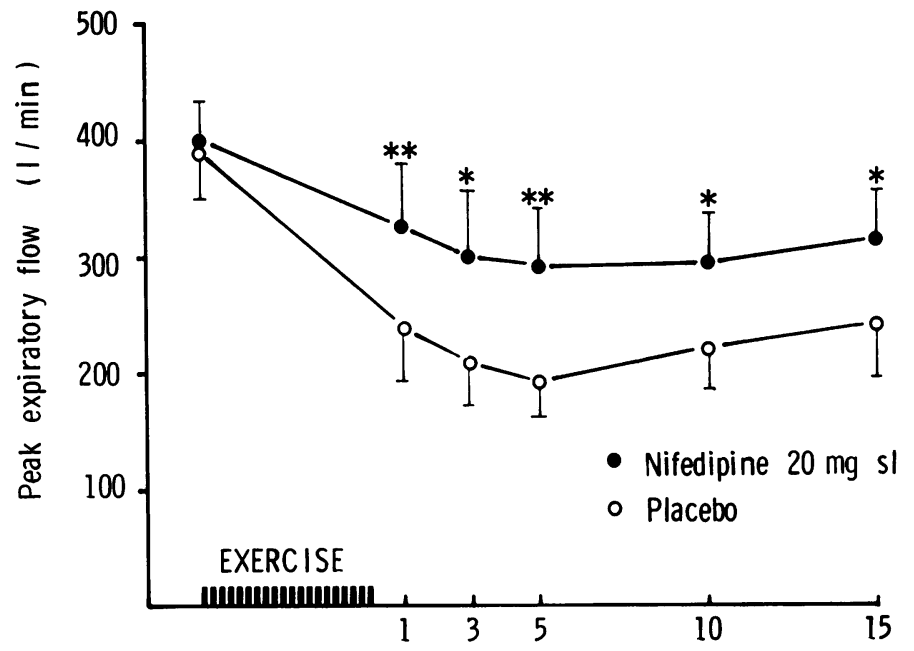

Fig 1 Peak expiratory flow in eight asthmatic subjects after treadmill exercise 30 minutes after taking nifedipine $20 \mathrm{mg}(\mathrm{O})$ or matched placebo $(\bigcirc)$. Values shown are mean \pm SEM. Difference between treated and control groups by Wilcoxon matched pairs, signed ranks test: ${ }^{* *}=p<0.01$, ${ }^{*}=p<0.05$.

Minutes after exercise

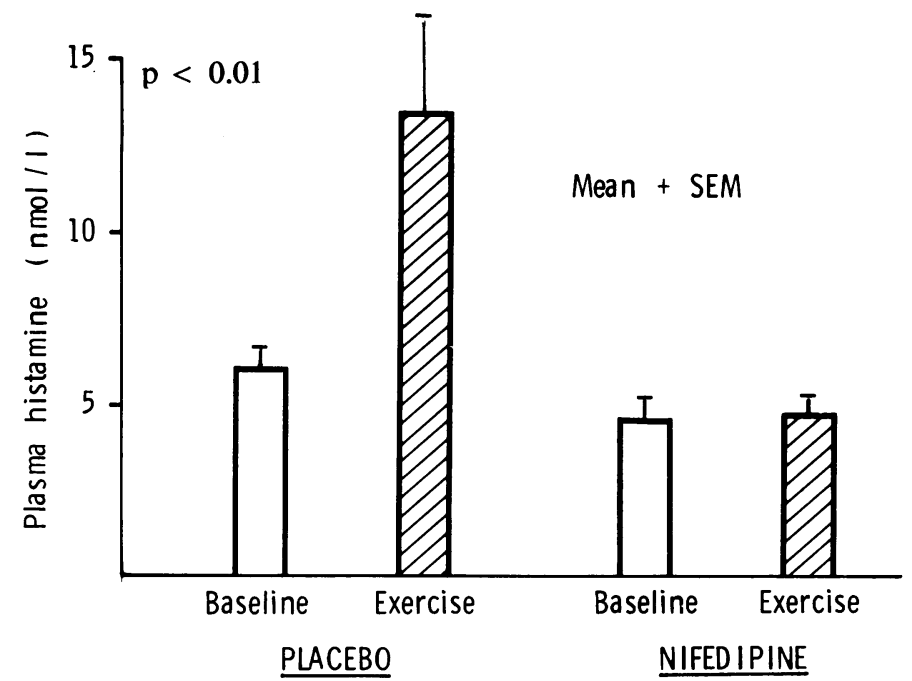

Fig 2 Venous plasma histamine levels before (baseline) and during the last minute of exercise in eight asthmatics after taking either placebo or nifedipine 20 mg. Values show mean + SEM.

histamine level was significantly lower $(\mathrm{p}<0.02) 30$ minutes after nifedipine than after placebo.

Histamine inhalation challenge was performed in five of the subjects. The $\mathbf{P C}_{20}$ was significantly greater ( $\mathrm{p}<0.05, t$ test) 90 minutes after nifedipine $(2.72 \pm 0.63 \mathrm{mg}$ histamine $/ \mathrm{ml})$ than after placebo $(1.53 \pm 0.31 \mathrm{mg}$ histamine $/ \mathrm{ml}$ ) (table 2). There was no significant difference between the PEF after the control solution between the nifedipine and placebo days.

\section{Discussion}

Nifedipine caused a small but significant reduction in post-exercise bronchoconstriction in asthmatic. subjects. Nifedipine is a potent inhibitor of trans- 꿍 membrane calcium ionic flux and does not appear to $\frac{O}{\mathbb{D}}$ have any other significant pharmacological actions $\stackrel{\odot}{\overparen{Q}}$ in the doses used therapeutically. ${ }^{5}$ This suggests that $\stackrel{\varnothing}{\varrho}$ EIA involves calcium-dependent processes.

In smooth muscle, ionic calcium from extra- 
cellular fluid and intracellular storage sites passes through specific "calcium channels" into the cytosol where it brings about excitation-contraction coupling. By inhibiting this calcium entry process calcium antagonists such as nifedipine produce a muscle relaxation in a variety of tissues. ${ }^{6-8}$ In anaesthetised dogs there is a reduction in resting tracheal tone with nifedipine, although this effect is less pronounced than its effect on tracheal blood flow, implying that it is less potent on airway than on vascular smooth muscle. ${ }^{9}$ With verapamil, a less potent calcium antagonist, there is an inhibitory effect on the contraction of canine trachealis muscle induced by potassium ions (depolarisation) and serotonin, but not by acetylcholine, ${ }^{10}$ suggesting that calcium antagonists may have less effect in vagally innervated tissues such as bronchial smooth muscle. ${ }^{11}$ We were unable to demonstrate any bronchodilator action 30 minutes after sublingual nifedipine. However, there was a small but significant protective effect against histamine-induced bronchoconstriction suggesting that nifedipine may have an effect on bronchial smooth muscle contractility. This confirmed a previous study in which nifedipine had a protective effect against histamine-induced bronchoconstriction in stable asthmatic subjects. ${ }^{12}$

The exact mechanism of EIA is uncertain but there is evidence that the release of bronchoconstrictor mast cell mediators may be involved. Cromoglycate stabilises pulmonary mast cells in vitro ${ }^{13}$ and has a protective effect against EIA. ${ }^{14} \mathrm{We}$ have recently demonstrated a rise in venous plasma histamine during exercise in asthmatics who develop EIA. ${ }^{15}$ Calcium ionic influx is involved in the release of mediators from mast cells ${ }^{16}$ and basophils, ${ }^{17}$ and the calcium antagonists lanthanum, ${ }^{18}$ quercitin, ${ }^{19}$ and cinnarazine ${ }^{20}$ inhibit antigen-induced release of mediators. There is preliminary evidence that nifedipine and verapamil in therapeutic concentrations inhibit antigen-induced release of histamine from sensitised human lung in vitro (Cerrina $\mathbf{J}$ et al, unpublished observations). The present study shows that in asthmatics given placebo there was a significant rise in venous plasma histamine concentration during exercise as previously reported, ${ }^{15}$ but with nifedipine no significant rise occurred, suggesting that nifedipine may inhibit release of mast cell mediators in vivo. There was also a small but significant decrease in the pre-exercise value of plasma histamine after nifedipine compared with placebo suggesting some inhibition of the tonic discharge of mast cell mediators in asthma.

The protective effect of nifedipine in EIA is however small. In only one subject was EIA completely inhibited by nifedipine; there was partial inhibition in five, but in two there was no inhibitory effect at all. This contrasts with the findings of Cerrina et $a l^{2}$ who showed complete inhibition of EIA in 10 asthmatic subjects given the same dose of nifedipine. Their subjects had less severe EIA than in the present study, however. Pharmacokinetic studies indicate that absorption from the buccal cavity is rapid, reliable, and complete and blood levels are in the therapeutic range at 30 and 90 minutes when the exercise and histamine challenges are performed. ${ }^{5}$ No significant fall in blood pressure or rise in heart rate occurred with nifedipine treatment, and it is therefore unlikely that baroreflex sympathetic activation could have occurred which might have modified EIA.

Although the effect of nifedipine is small, it does support the suggestion that calcium ionic flux is involved in the pathogenesis of EIA. The complete inhibition of the rise in plasma histamine during exercise with nifedipine contrasts with an only partially inhibitory action on EIA, which suggests that other mechanisms such as vagal reflex activation are also involved. It is also possible that the rise in plasma histamine during exercise in asthmatics reflects release from circulating basophils rather than from pulmonary mast cells, and the inhibitory effect of nifedipine may therefore be due to an action on basophils rather than on mast cells in the lung, although it is likely that the same calcium-dependent processes occur in the two cell types. The small protective effect of nifedipine on histamine-induced bronchoconstriction indicates that an action on bronchial smooth muscle may also contribute to the inhibitory effect on EIA.

The protective effect is too small to make nifedipine useful therapeutically in asthma but it is possible that new calcium antagonists may be developed which are more specific in effect for bronchial smooth muscle and mast cells. Using the inhaled route it may be possible to achieve higher concentrations of drug in the lung without systemic side effects. When the calcium antagonist verapamil was given by nebuliser it had a protective effect against EIA comparable with that of cromoglycate. ${ }^{21}$ Nifedipine is an effective treatment for angina pectoris, ${ }^{20-24}$ and these studies suggest that it may confer some additional benefit in patients with asthma. There is some evidence for an improvement in airflow obstruction during chronic nifedipine treatment in patients with chronic asthma. ${ }^{25}$ By contrast, beta-adrenergic antagonists used in treating angina may precipitate bronchoconstriction in asthmatics ${ }^{26}$ and chronic bronchitics, ${ }^{27}$ and even "cardioselective" beta-blockers should be avoided. Asthmatic patients who have angina might therefore be more appropriately treated with nifedipine than with beta-adrenergic antagonists. 
We would like to thank Dr NB Pride for helpful discussion and Dr G MacDonald, Bayer UK, for supplying nifedipine and placebo capsules.

\section{References}

${ }^{1}$ Middleton E. Antiasthmatic drug therapy and calcium ions; review of pathogenesis and the role of calcium. $J$ Pharm Sci 1980;69:243-51.

${ }^{2}$ Cerrina J, Denjean A, Alexandre G, Lockhart A, Duroux P. Inhibition of exercise-induced asthma by a calcium antagonist, nifedipine. Am Rev Respir Dis 1981;123: 156-60.

${ }^{3}$ Chai H, Farr RS, Froehlich LA et ai. Standardisation of bronchial inhalation challenge procedures. $J$ Allergy Clin Immunol 1975;56:323-7.

${ }^{4}$ Brown MJ, Ind PW, Barnes PJ, Jenner DA, Dollery CT. A sensitive and specific radiometric method for the measurement of plasma histamine in normal individuals. Anal Biochem 1980;109:142-6.

${ }^{5}$ Ebner F, Dunschede HP. Haemodynamics, therapeutic mechanism of action and clinical findings of Adalat use based on individual clinical trial. In: Jatene AD, Lichtlen PR, eds. New therapy for ischaemic heart disease. Amsterdam: Excerpta Medica, 1976:283-300.

${ }^{6}$ Fleckenstein A, Fleckenstein-Grun G, Byon YK, Haastert HP, Späh F. Vergleichende Untersuchungen uber die $\mathrm{Ca}^{++}$-antagonistischen Grundwirkurgen von Niludipin und Nifedipine auf Myocard, Myometrium und glatte Gefassmuskulatur. Arzneim-Forsch 1979;29:230-46.

7 Ulmsten U, Andersson KE, Forman A. Relaxing effects of nifedipine on the non-pregnant human uterus in vitro and in vivo. Obstet Gynaec 1978;52:436-4.

${ }^{8}$ Forman A, Anderson KE, Henrikksson L, Rud T, Ulmsten U. Effects of nifedipine on the smooth muscle of the human urinary tract in vitro and in vivo. Acta Pharm Toxicol 1978;43:111-8.

${ }^{9}$ Himori N, Taira N. Differential effects on the calciumantagonistic vasodilators nifedipine and verapamil on the tracheal musculature and vasculature of the dog. $\mathrm{Br}$ J Pharmacol 1980;68:595-7.

${ }^{10}$ Coburn RF. The airway smooth muscle cell. Fed Proc 1977;36:2692-7.

${ }^{11}$ Farley JM, Miles PR. Role of depolarisation in acetylcholine-induced contractions of dog trachealis muscle. J Pharmacol Exp Ther 1977;201:199-205.
12 Williams DO, Barnes PJ, Vickers HP, Rudolf M. Effect of nifedipine on bronchomotor tone and histamine reactivity in asthma. $\mathrm{Br} \mathrm{Med} J 1981 ; \mathbf{2 8 3}: 348$.

${ }^{13}$ Cox JSG. Disodium cromoglycate: a specific inhibitor of antibody antigen mechanisms. Nature 1967;216:1328-9.

${ }_{11}$ Davies SE. Effect of disodium cromoglycate on exerciseinduced asthma. Br Med J 1968;3:593-4.

15 Barnes PJ, Brown MJ. Venous plasma histamine in exercise and hyperventilation induced asthma in man. Clin Sci $1981 ; 61: 159-62$.

${ }^{16}$ Foreman JC, Mongar JL. Effect of calcium on dextran induced histamine release from isolated mast cells. $\mathrm{Br} \mathrm{J}$ Pharmacol 1972;46:767-9.

${ }^{17}$ Lichtenstein LM. The mechanism of basophil histamine $\omega$ release induced by antigen and by the calcium ionophore A23187. J Immunol 1975;114:1692-9.

18 Foreman JC, Mongar JL. The action of lanthanum and manganese on anaphylactic histamine secretion. $B r J$ Pharmacol 1973;48:527-37.

${ }^{19}$ Fewtrell CMS, Gomperts BD. Quercitin: a novel inhibitor of $\mathrm{Ca}^{2+}$ influx and exocytosis on rat peritoneal mast cells. Biochem Biophys Acta 1977;469:52-60.

${ }^{20}$ Barrett-Bee KJ. Ionophore- and antigen-induced histamine release from mast cells and a comparison of their inhibition. Biochem Soc Trans 1977;5:965-7.

${ }^{21}$ Patel KR. Calcium antagonists in exercise-induced asthma. $\vec{\oplus}$ Br Med J 1981;282:932-3.

${ }^{22}$ Ekelund LG, Oro L. Anti-anginal efficiency of nifedipine with and without a beta-blocker studied with exercise test. A double blind, randomised subacute study. Clin Cardiol 1979;2:203-11.

${ }^{23}$ Moskowitz RM, Piccini PA, Nacarelli GV, Zelis R. Nifedipine therapy for stable angina pectoris; preliminary results of effects on angina frequency and treadmill exercise response. Am J Cardiol 1979;44:811-6.

${ }^{24}$ Lynch P, Dargie H, Krikler S, Krikler D. Objective assessment of antianginal treatment: a double blind comparison of propanolol, nifedipine and their combination. Br Med J 1980;2:184-7.

${ }^{25}$ Jaiprakash SS, Sahay JN, Chatterjee SS, MacDonald G. Efficiency of nifedipine in the treatment of angina pectoris and chronic airways obstruction. Postgrad Med $J$ 1980;56:624-8.

${ }^{26} \mathrm{McNeill}$ RS, Ingram CG. Effect of propranolol on ventilatory function. Am J Cardiol 1966;18:473-5.

27 Sinclair DJM. Comparison of effects of propranolol and metoprolol on airways function in chronic bronchitis. Br Med J 1979;1:168-70. 